\title{
Aspekte van mediumenergie-kernfisika in Suid-Afrika
}

\author{
A.A. Cowley \\ Departement Fisika, Universiteit van Stellenbosch, Stellenbosch, 7600 \\ Ontvang 5 Mei 1994; aanvaar 5 Julie 1994
}

\section{UITTREKSEL}

Slegs agt jaar gelede het Suid-Afrika toegetree tot fundamentele navorsing in mediumenergie-kernfisika toe die siklotronfasiliteit van die Nasionale Versnellersentrum in bedryf gestel is. Die navorsingswerk wat ondertussen uitgevoer is, het al reeds 'n beduidende impak op die vakgebied gehad. Hierdie oorsig van 'n aantal geselekteerde projekte wat onderneem is, illustreer die wyse waarop 'n bydrae tot die vak gelewer is en toon hoe dit tot 'n beter begrip van die atoomkern lei. Die belofte wat hierdie basiese navorsing vir toekomstige toepassings inhou, word met twee belangrike voorbeelde beklemtoon.

\section{Abstract \\ Aspects of medium-energy nuclear physics in South Africa \\ South Africa has participated in basic research on medium-energy nuclear physics for the past eight years since the completion of the cyclotron facility of the National Accelerator Centre. The research projects that have been conducted during this period have had a major influence on the development of the discipline of nuclear physics. This review of a selection of projects that have been completed to date illustrates the advance of knowledge and how this work has contributed towards a further understanding of the atomic nucleus. The possible impact of these studies on future application is alluded to by means of two important illustrative examples.}

\section{INLEIDING}

Suid-Afrika beskik oor 'n mediumenergie-versneller wat sekere unieke moontlikhede aan mediese toepassings, isotoopproduksie en basiese navorsing bied. Sommige belangrike parameters van die beskikbare fasiliteite van die Nasionale Versnellersentrum(NVS) word in tabel 1 saamgevat.

Enkele navorsingsprojekte ${ }^{1-15}$ wat uitgevoer is sedert die inbedryfstelling van die sentrum in November 1986 word wat basiese kernfisika betref, toegelig.

TABEL 1 Parameters van die oopsektorsiklotron en lys van toerusting vir basiese kernfisika

\begin{tabular}{lll|}
\hline $\begin{array}{l}\text { Versneller: } \\
\text { Versnelde }\end{array}$ & $\begin{array}{l}\text { Energie/ } \\
\text { nukleon }(\mathrm{MeV} / \mathrm{u})\end{array}$ & $\begin{array}{l}\text { Bundel- } \\
\text { intensiteit }(\mu \mathrm{A})\end{array}$ \\
$\mathrm{p}$ & $27-220$ & 200 \\
$\mathrm{~d}$ & $35-40$ & 2 \\
$\alpha$ & $30-50$ & 2 \\
\hline Apparatuur: & & \\
& & \\
Magnetiese spektrometer & \\
Bundelswaaier vir neutronvlugtyd \\
Verstrooiingskamer (1.5 m middellyn) \\
Sekondêre neutronbundel
\end{tabular}

Die verskillende aspekte wat beskryf word, is:

- Energieoordrag aan kernmaterie ${ }^{1-7}$

- Kwasievrye uitslaan van nukleon ${ }^{8.9}$

- Protonemissie geïnduseer deur protone $e^{10-13}$

- Groeperings van nukleone in kernmaterie ${ }^{14}$

- Pionproduksie onder die nukleon-nukleon-drumpelenergie $^{15}$

\section{ENERGIEOORDRAG AAN KERNMATERIE DEUR NUKLEONE}

Versnelde projektiel-nukleone met lae kinetiese energie wat met atoomkerne bots, kan energie oordra in 'n reeks botsings met die individuele protone en neutrone waaruit die kern bestaan, en sal sodoende uiteindelik ingevang word deur die skyfkern. Die saamgestelde kern wat sodoende ontstaan het, het gevolglik 'n relatief hoë interne opwekenergie. As deur verdere interne botsing tussen die partikels in hierdie saamgestelde tussenkern 'n enkele nukleon egter toevallig genoeg energie op homself gekonsentreer kry, kan sodanige nukleon ontsnap. Uiteraard sal so 'n proses op 'n relatief lang tydskaal (sê $10^{-15} \mathrm{~s}$ ) plaasvind in vergelyking met die tyd wat dit neem vir 'n projektiel om sonder interaksie oor die kerngrootte te beweeg.

As die projektieldeeltjie egter oor genoegsame kinetiese energie beskik, kan die interaksie volgens 'n direkte meganisme verloop, d.w.s. een enkele botsing met die teikenkern vind plaas en die brokstukke wat ontstaan verkeer slegs in wisselwerking met mekaar vir 'n tydsduur 
wat vergelykbaar is met die vlugtyd van die projektiel. Hierdie tydsduur is aan die orde van $10^{-21} \mathrm{~s}$.

Die twee prosesse, nl. tussenkernvorming en direkte interaksies, was vir baie jare welbekend voordat 'n kernreaksietipe in 1966 ontdek is wat duidelik nie by een van die twee ekstreme gevalle ingepas het nie. Hierdie hierdie ondersoek verkry word, versoenbaar met die bekende gedrag van 'n optiese potensiaal (sien fïguur 3 ).

Verdere ondersoek ${ }^{6,7}$ van skyfkerne in die massagebied tussen 58 en 197 atoommassa-eenhede oor 'n wye gebied van invalsenergie tot $200 \mathrm{MeV}$ bevestig die akkuraatheid waarmee die SDM-teorie die reaksieproses beskryf. Nogtans

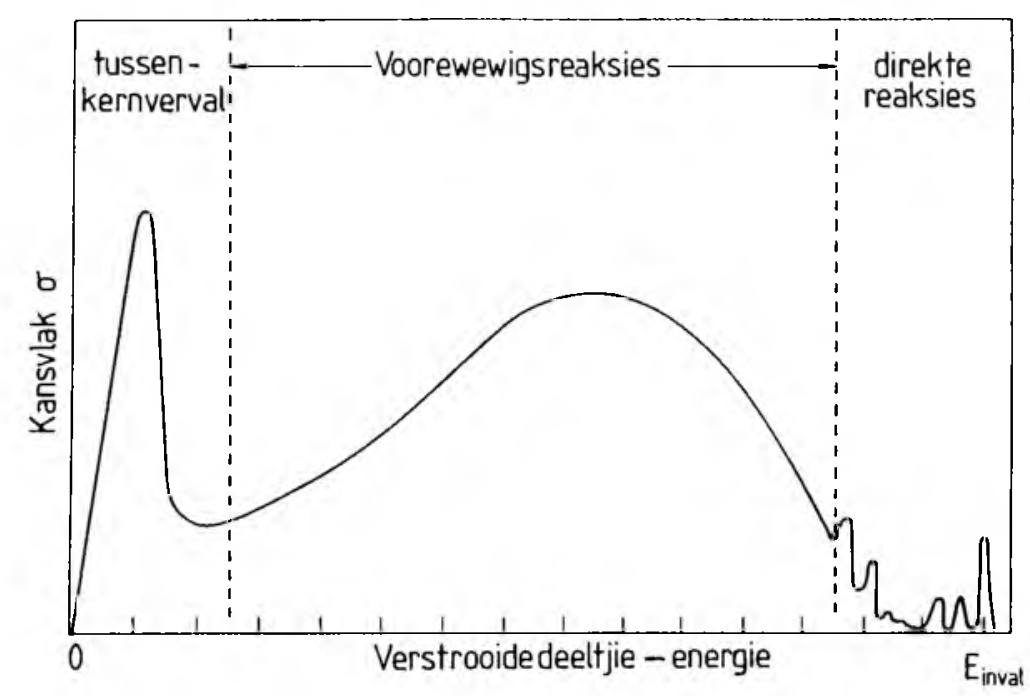

FIGUUR 1: 'n Skematiese voorstelling van die energiespektrum van protone wat na 'n bepaalde hoek deur 'n atoomkern verstrooi is. Die drie gedeeltes van die spektrum, wat met verskillende reaksiemeganismes geassosieer word, word aangedui.

nuwe, sogenaamde voorewewigsreaksieverskynsel, het duidelik eienskappe getoon wat intermediêr is tussen die twee uiterste gevalle, en baie gou is ontdek dat hierdie reaksieproses 'n al groter wordende breuk van die totale reaksiewaarskynlikheid verteenwoordig namate die projektielenergie toeneem.

Vir die volledige kwantummeganiese beskrywing van voorewewigsreaksies is aanvanklik van semi-klassieke modelle gebruik gemaak as riglyn vir die teoretiese beskrywing. Verdere eksperimente is bedink waarteen die teorieë getoets kon word. Sodoende is moontlike leemtes opgespoor wat ontstaan a.g.v. benaderings wat noodwendig gemaak moes word ter wille van wiskundig-hanteerbare formulering.

'n Voorstel]ing van die energiespektrum vir die reaksie (p,p') by 'n spesifieke verstrooiingshoek word in figuur 1 gegee, met ' $n$ aanduiding van die drie gebiede wat met die verskillende reaksiemaganismes geïdentifiseer word. Eksperimentele hoekverdelings van die kansvlakke vir geselekteerde uitgangsenergie word in figuur 2 vergelyk met voorspellings van die statistiese direkte multistapteorie (SDM-teorie) van Feshbach, Kerman en Koonin ${ }^{16}$ vir die reaksie ${ }^{9} \mathrm{Zr}(\mathrm{p}, \mathrm{p}$ '). (Let op dat met die weglating van die eindkern in die notasie impliseer word dat die reaksieproses inklusief mag wees, m.a.w. die waargenome proton mag dalk gelyktydig met ander ligte produkdeeltjies tydens die kernreaksie vrygestel word.)

Dit is duidelik uit die ooreenstemming tussen die gemete en teoretiese hoekverdelings dat hierdie SDM benadering tot die reaksiemeganisme redelik bevredigend is. Ook wat betref die effektiewe nukleon-nukleon-wisselwerkingsterkte soos dit in 'n kernmedium optree, is die resultate wat in

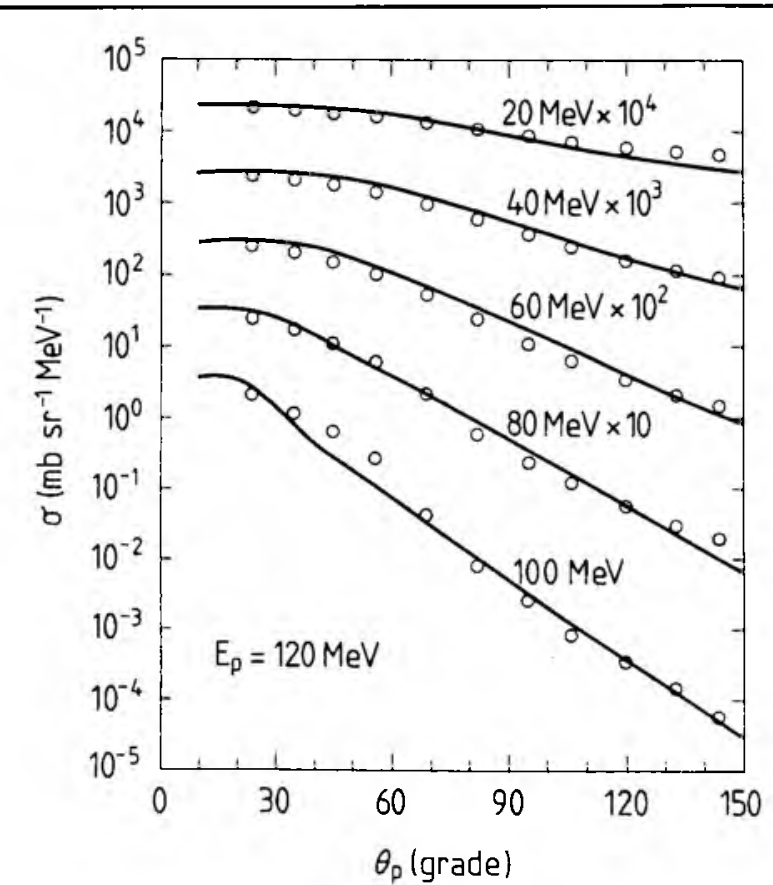

FIGUUR 2: Hoekverdelings vir die reaksie ${ }^{90} \mathrm{Zr}\left(p, p^{\prime}\right)$ by 'n projektielenergie $E_{p}$ van $120 \mathrm{MeV}$ en met verskeie uitgangsenergie ë soos aangedui. Die krommes is die voorspelling van die statistiese direkte multistap-teorie van Feshbach, Kerman en Koonin. ${ }^{16}$ Resultate is vermenigvuldig met die aangeduide skaalfaktore om die gegewens duideliker aan te toon. 


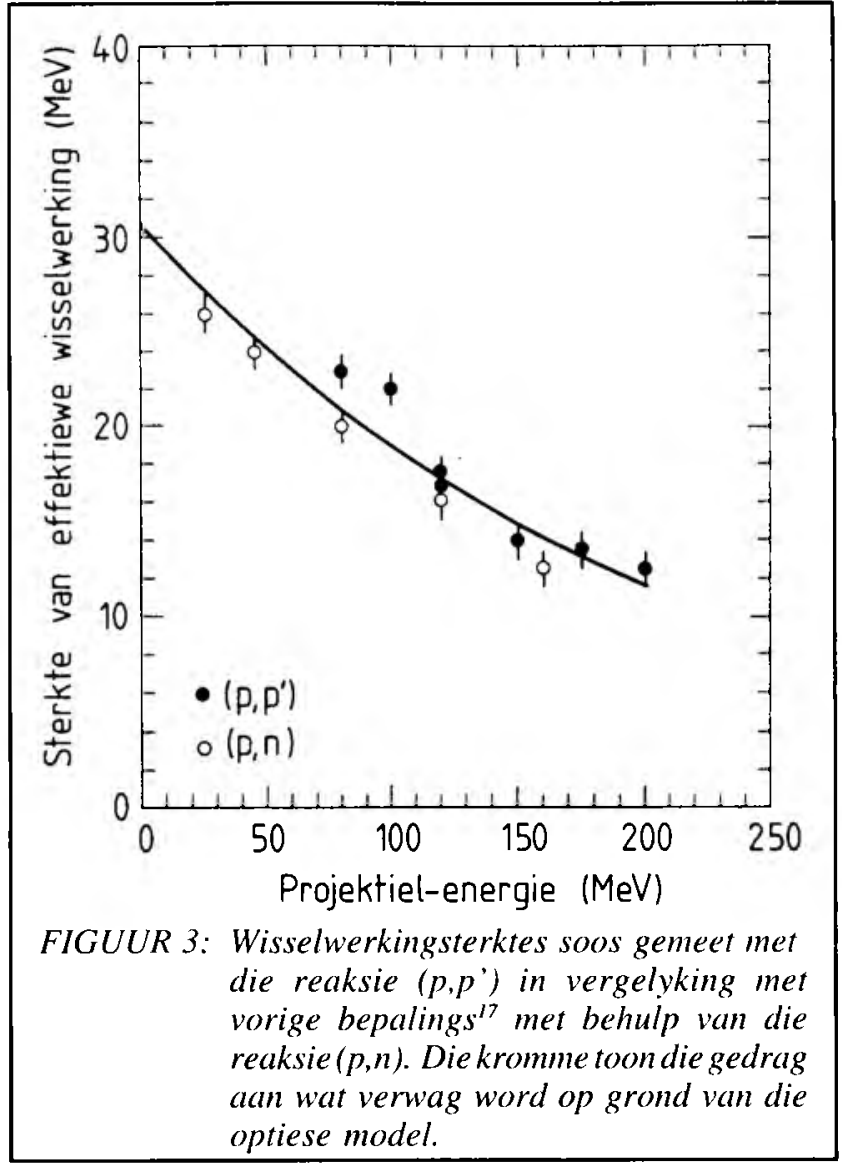

is gevind dat by geringe opwekking van die skyfkern 'n uitslaanproses ook 'n belangrike rol speel, ${ }^{6}$ sodat dit wenslik sou wees om so ' $n$ reaksiemeganisme in die SDM-teorie in te bou. Insluiting van hierdie, asook ander verfynings in die teoretiese beskrywing van die reaksieproses, geniet tans die aandag van 'n groot aantal navorsers regoor die wêreld. Die studies wat tot dusver by die NVS uitgevoer is, soos beoordeel in die nuutste oorsig ${ }^{18}$ van hierdie navorsingsgebied, het 'n deurslaggewende bydrae tot hierdie kennis gemaak.

\section{KWASIEVRYE UITSLAAN VAN NUKLEONE}

Ecn van die belangrikste deurbrake in kernfisika is die kennis dat talle eienskappe van atoomkerne versoenbaar is met die beeld dat die nukleone, waaruit die kern bestaan, tot goed gedefinieerde skille beperk word (orbitale of toestande met ' $n$ bepaalde energie en 'n bepaalde stel kwantumgetalle). Vanselfsprekend sou dit moontlik wees om sulke nukleone uit hulle orbitale uit te slaan in 'n kernreaksie met 'n energieke projektieldeeltjie, sodat so 'n proses lig kan werp op die besetting van skiltoestande, bindingsenergieë en momentumverdelings van kernnukleone.

Indien ' $n$ projektiel 'n stilstaande nukleon in 'n atoomkern tref, is dit baie waarskynlik dat die reskern, wat oorbly nadat die uitslaanproses plaasgevind het, suiwer as 'n toeskouer tot die reaksie optree. Momentumbehoud vereis dan dat die reskern in rus bly, en so 'n reaksie word dan 'n kwasievrye proses genoem, omdat dit by benadering soos 'n vrye botsing tussen die projektiel en teikennukleon verloop.

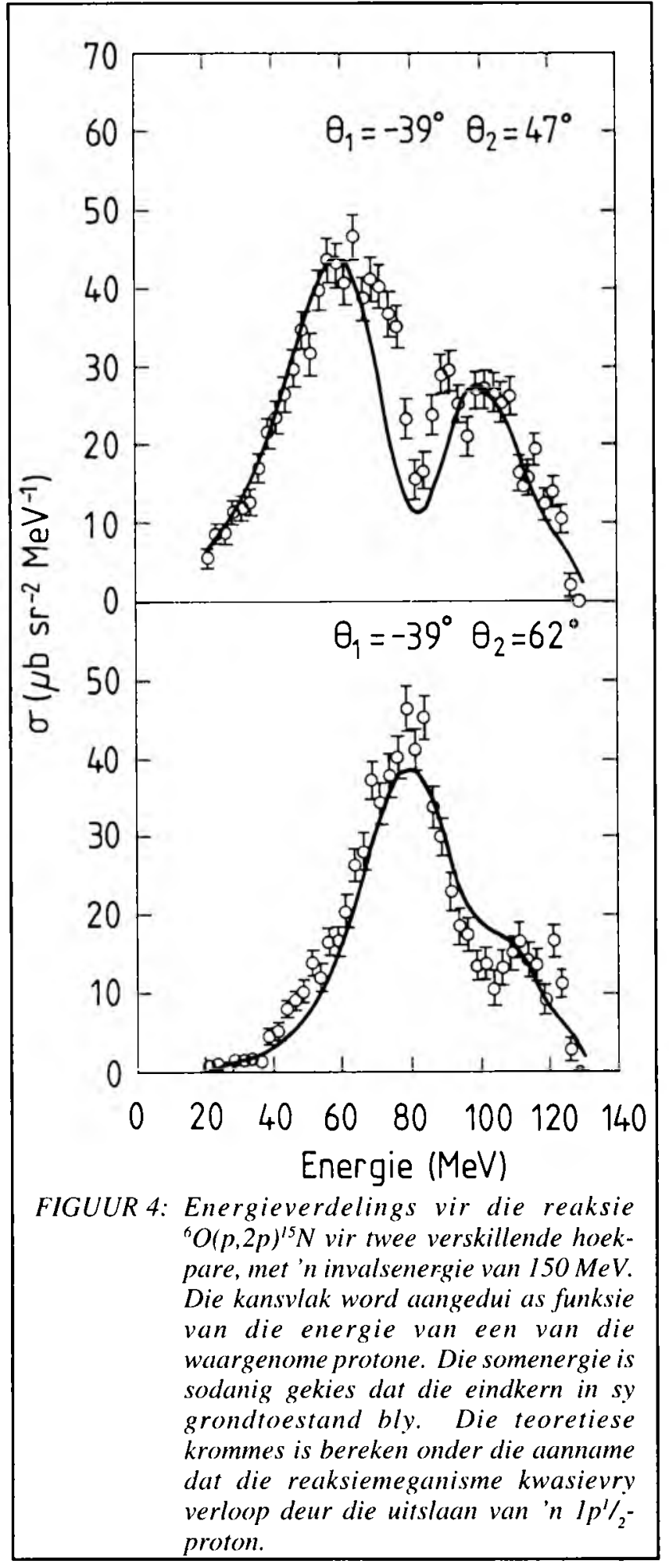

Alhoewel kwasievrye uitslaanreaksies alreeds baie jare bestudeer word, kon nog steeds belangrike bydraes gemaak word tot insig in die dinamiese verskynsels wat tydens hierdie tipe reaksie optree. 'n Voorbeeld hiervan word in figuur 4 getoon, waar eksperimentele resultate ${ }^{9}$ vir die reaksie ${ }^{16} \mathrm{O}(\mathrm{p}, 2 \mathrm{p}){ }^{15} \mathrm{~N}$ vergelyk word met teoretiese voorspellings. Die treffende ooreenkoms tussen die gemete en berekende energieverdelings dui daarop dat die reaksiemeganisme wel korrek geïdentifiseer word. Verder kon aangetoon word dat die besetting van die twee valensorbitale 
van ${ }^{16} \mathrm{O}$ volgens verwagting is. Gevolglik word die reaksieproses nou so goed verstaan dat hierdie eksperimentele tegniek toegepas kan word op teikenkerns waarvoor teoretiese berekenings nie prakties moontlik is nie.

\section{PROTONEMISSIE GEÏNDUSEER DEUR PROTONE}

'n Proton wat met 'n skyfkern bots, sal vanselfsprekend verskeie tipes reaksies volgens verskillende waarskynlikhede ondergaan. As een bepaalde reaksie in 'n eksperiment oorheers, is dit gevolglik dikwels weens die feit dat die eksperimentele omstandighede doelbewus so gekies is dat slegs daardie spesifieke reaksiekanaal bevoordeel word. In die praktyk beteken dit noodwendig dat die eksperimentalis versigtig moet wees om die invloed van kompeterende reaksieverskynsels in gedagte te hou.

'n Voorbeeld hiervan word gevind by studies van voorewewigsreaksies waar, soos reeds genoem, nie uit die oog verloor moet word nie dat die gelyktydige vrystelling van twee nukleone volgens die kwasievrye reaksie ook 'n moontlikheid is. Die wedersydse invloed van hierdie twee kompeterende prosesse op mekaar moet dus verstaan word.

'n Hele paar studies ${ }^{1-7}$ is reeds die afgelope paar jaar uitgevoer en 'n tipiese resultaat' word in figuur 5 getoon. Soos gesien kan word, is die gemete koïnsidensiespektra in ooreenstemming met die teoretiese voorspellings van die voorgestelde reaksiemeganisme.

Dit word afgelei dat twee-nukleonemissie gedryf word deur die kinematiese beperkings wat gestel word deur 'n aanvanklike kwasievrye botsing van die projektiel. Die skyfnukleon tree vervolgens op soos ' $n$ intrakern-projektiel en veroorsaak verdere opwekkings van die reskern volgens 'n voorewewigsmeganisme. Die aanvanklike rigtings wat die oorspronklike kwasievrye botsing aan die nukleonpaar toesê, bly deurgaans voorkeurrigtings. Gevolglik behou die hoekverdelings van die energiespektra die aard wat karakteristiek is van 'n kwasievrye interaksie.

Die eenvoudige wyse waarvolgens hierdie reaksie verloop, is verrassend, en ook verblydend. Dit beteken dan

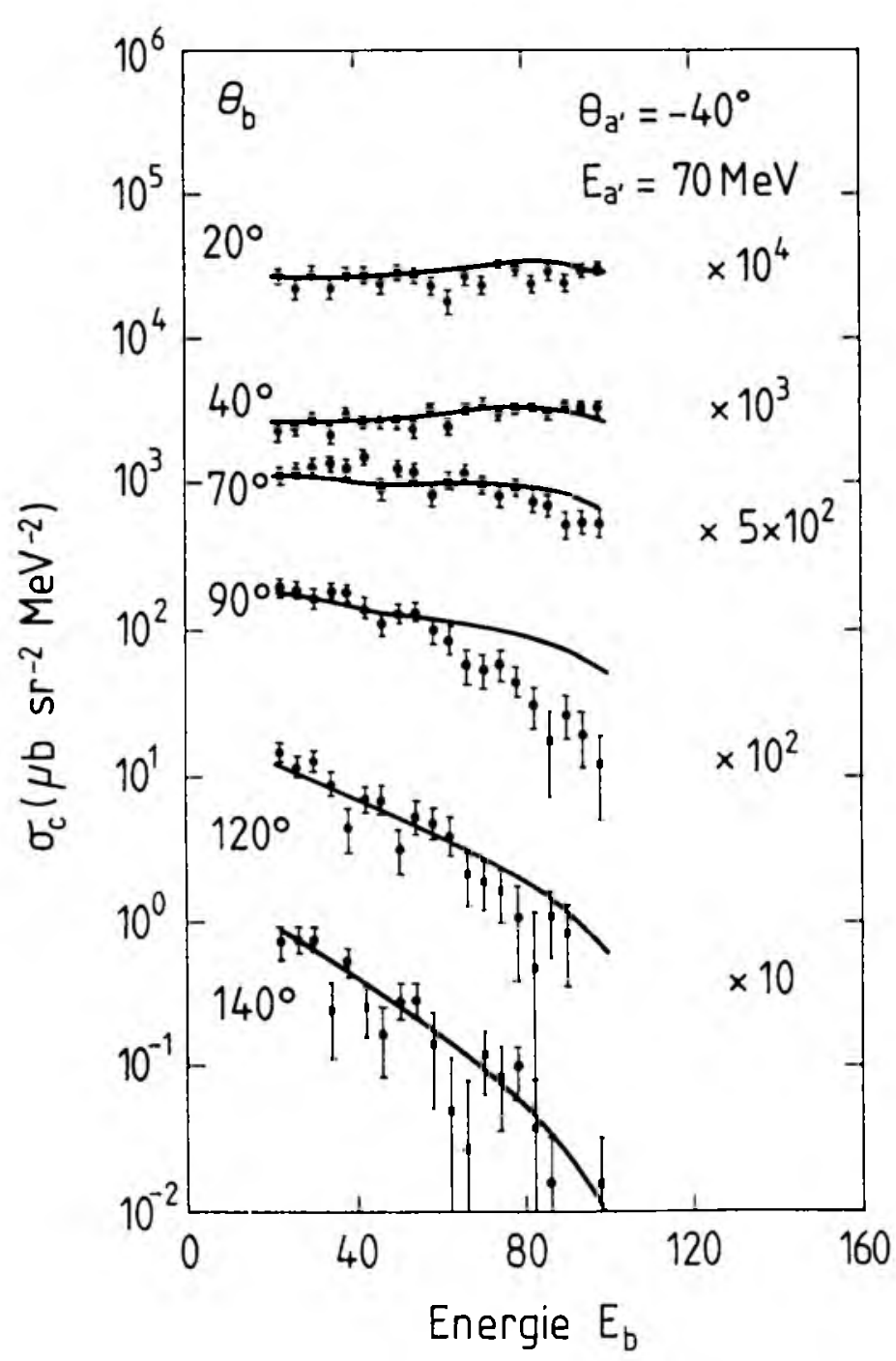

FIGUUR 5: Kö̈nsidensiespektrum vir die reaksie ${ }^{197} A u(p, p$ ' $p$ ฟ) by 'n projektielenergie van $200 \mathrm{MeV}$. Verstrooiingshoeke en energieë word aangedui met voetskrifte wat die notasie $\left(a, a^{\prime} b\right)$ aan die reaksie koppel. Die teoretiese krommes is bereken volgens die model wat in die teks beskryf word. Resultate is vermenigvuldig met die aangeduide skaalfaktore om die gegewens duideliker aan te toon. 
ook dat dit in beginsel maklik moet wees om voorewewigsverskynsels en kwasievrye uitslag op 'n geintegreerde grondslag teoreties te behandel.

\section{GROEPERINGS VAN NUKLEONE IN KERNMATERIE}

Dit is reeds talle jare bekend dat nukleone tydelike groeperings kan inneem namate hulle in die atoomkern beweeg. Gevolglik is dit moontlik om sulke "klonte"van nukleongroeperings met 'n projektieldeeltjie uit te slaan, ten einde die waarskynlikheid vir klontvorming te bepaal. Een van die belangrikste vrae oor die jare heen was of die klontvormingswaarskynlikheid in kernmaterie versoenbaar is met die riglyne wat gegee word deur die skilmodel, al dan nie. Eksperimente ${ }^{19}$ met protone as projektieldeeltjies het wel bevestig dat die verwagting volgens die skilmodel korrek blyk te wees. Daarenteen, as dieselfde studie uitgevoer ${ }^{20}$ word met alfadeeltjies as projektiel, is waardes vir die klontvormingswaarskynlikheid gevind wat ordegroottes van die vorige resultaat verskil.

Een van die moontlike verklarings vir die waargenome verskynsel is dat daar leemtes mag wees in die beskrywing van die buitenste gedeelte van die skyfkern, met ' $n$ gepaardgaande onakkuraatheid van die verloop van die golffunksie in daardie gebied. Gevolglik is dit onder sulke omstandighede verstaanbaar dat metings onbetroubaar sal wees as dit uitgevoer word in ' $n$ radiale gebied van die kern waar die klontgolffunksie gedaal het tot 'n baie klein waarde, met 'n gepaardgaande groot onsekerheid in die absolute grootte. Aangesien protonprojektiele dieper in die teikenkern indring as $\alpha$-deeltjies met dieselfde invalsenergie, sal dit dan die waargenome gedrag verklaar.

Die teenstrydige resultate wat vantevore verkry is met twee reaksies ${ }^{19,20}$ op dieselfde skyfkern, $n l .{ }^{9} \mathrm{Be}(\mathrm{p}, \mathrm{p} \alpha)^{5} \mathrm{He}$ en ${ }^{9} \mathrm{Be}(\alpha, 2 \alpha)^{5} \mathrm{He}$, is onlangs verder ondersoek deur laasgenoemde reaksie by 'n hoër invalsenergie te herhaal sodat die projektiel dieper in die skyfkern kan indring.

Die mate van indringing word in figuur 6 geillustreer, waar die bydrae tot die kansvlak as funksie van die radiale afstand in die skyfkern vertoon word vir die reaksie ${ }^{9} \mathrm{Be}(\alpha, 2 \alpha){ }^{5} \mathrm{He}$ by drie verskillende waardes van $\alpha$ invalsenergie. (Slegs die twee laer energieë is vantevore vir eksperimentele ondersoeke benut.) Hieruit blyk dit duidelik dat die maksimum bydrae by kleiner radiale posisie voorkom namate die invalsenergie verhoog word.

Die resultate wat in die nuwe eksperiment op ${ }^{9} \mathrm{Be}(\alpha, 2 \alpha)^{5} \mathrm{He}$ by ' $\mathrm{n}$ invalsenergie van $200 \mathrm{MeV}$ verkry is, word in figuur 7 getoon. Hieruit kan afgelei word dat die aard van die reaksiemeganisme bevestig word, soos bewys word deur die goeie ooreenstemming tussen die gemete en berekende energieverdelings. Terselfdertyd is ook gevind dat die gemete klontvormingswaarskynlikheid skynbaar drasties afgeneem het met die toename in invalsenergie, en dat dit nou inderdaad ooreenstem met die waarde wat verkry is met 'n proton as projektiel. Dit beteken dus dat die oënskynlike anomalie tussen die reaksies (p,p $\alpha)$ en $(\alpha, 2 \alpha)$ wat vantevore gevind is, fundamenteel teruggevoer kan word na die gebrek aan voldoende indringing in die skyfkern by die vorige studies.

Hierdie bevinding impliseer dat die $(\alpha, 2 \alpha)$ reaksie wel gehruik kan word om klontvormingswaarskynlikhede in atoomkerne te ondersoek, mits sorg gedra word dat die projektielenergie hoog genoeg is om in die kern in te dring tot 'n gebied waar die digtheid 'n waarde het waarby daar nie onsekerheid bestaan oor sommige ander eienskappe van kernmaterie nie.

\section{PIONPRODUKSIE VÊR ONDER DIE VRYE NUKLEON-NUKLEON-DRUMPELENERGIE}

Kort nadat Yukawa sy teorie ${ }^{21}$ bekendgestel het waarvolgens die sterk wisselwerking sy oorsprong het in die uitruil van mesone, is ' $n$ deeltjieversneller by Berkeley ontwerp om hierdie deeltjie kunsmatig te produseer. Kort daarna is so 'n soort deeltjie in kosmiese straling ontdek, en ook met 'n kernreaksie geproduseer.

Volgens die mesonbeskouing van die sterk wisselwerking word mesone uitgeruil tussen nukleone wat in wisselwerking

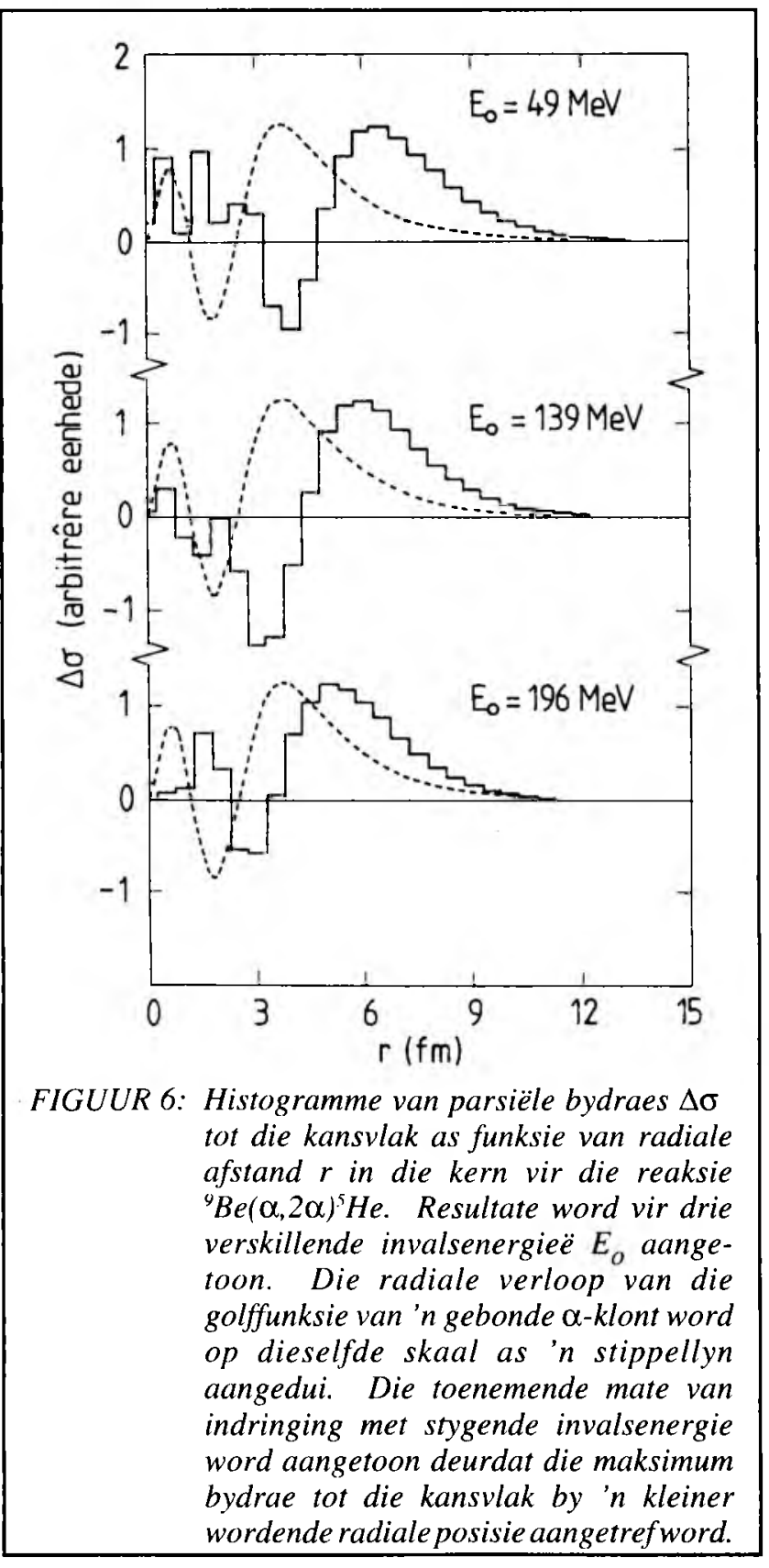




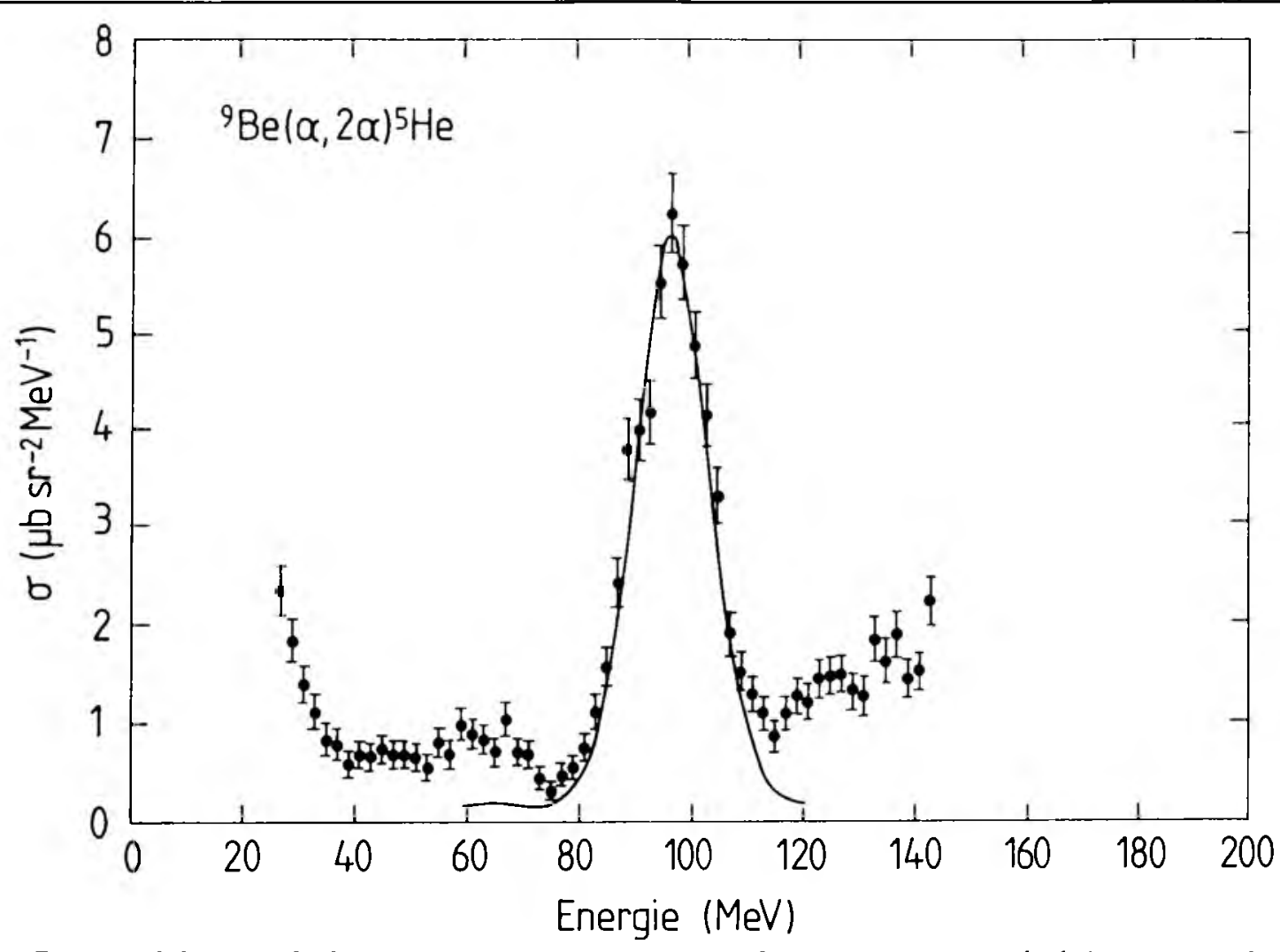

FIGUUR 7: Kansvlak $\sigma$ as funksie van energie van een van die waargenome $\alpha$-deeltjies wat in die reaksie ${ }^{9} \mathrm{Be}(\alpha, 2 \alpha)^{5} \mathrm{He}$ by 'n invalsenergie van $200 \mathrm{MeV}$ vrygestel word. Die hoekpaar is 'n samevlakkige kwasievry simmetriese stel, sodat die terugslagkern in rus verkeer na die interaksie wanneer die beskikbare deel van die invalsenergie gelykop tussen die uitgaande $\alpha$-deeltjies verdeel word. Die kromme verteenwoordig die teoretiese voorspelling, uitgaande van die aanname dat kwasievrye uitslag van 'n klont plaasvind.

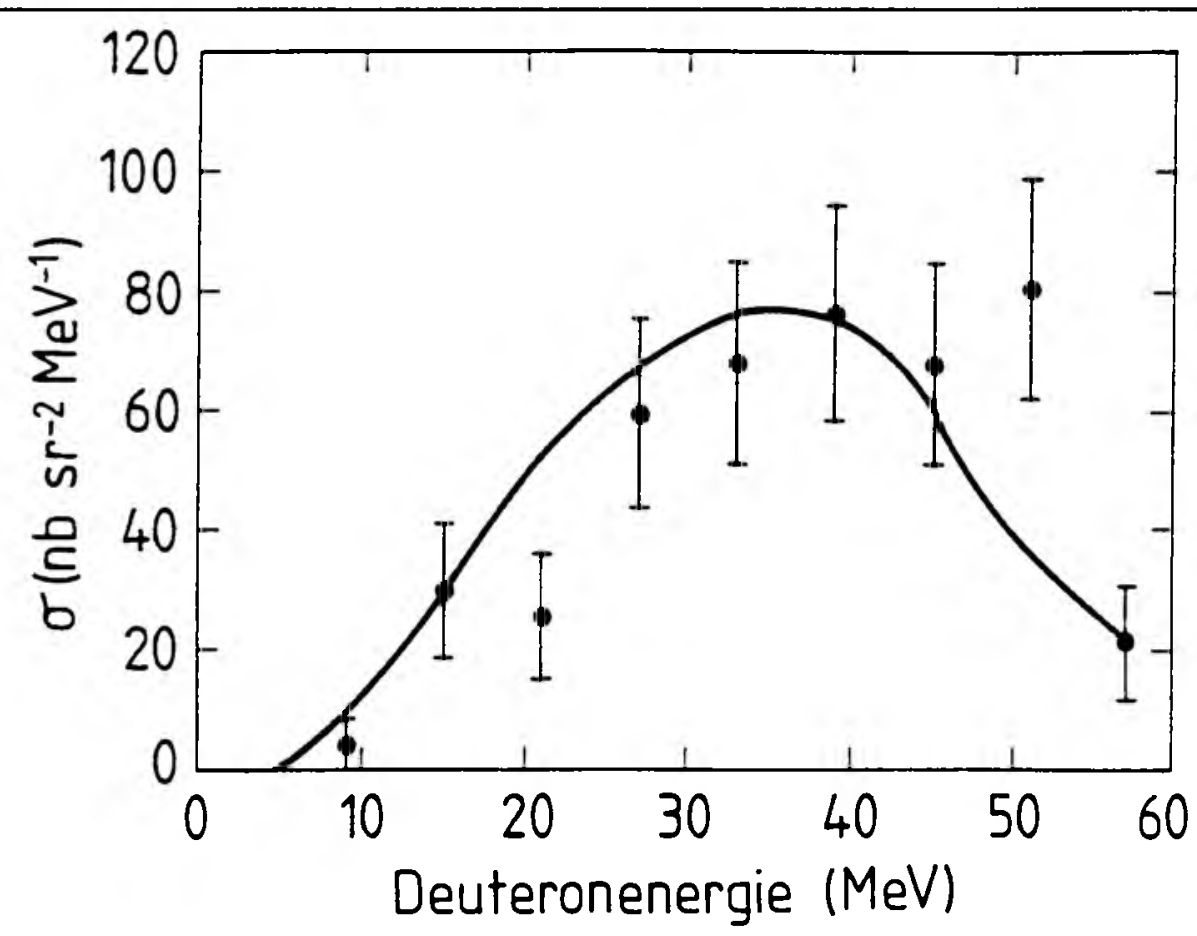

FIGUUR 8: Kansvlak $\sigma$ as funksie van deuteronenergie vir die reaksie ${ }^{12} C\left(p, d \pi^{+}\right)^{\prime \prime} B$ by 'n invalsenergie van $220 \mathrm{MeV}$. Die teoretiese kromme voorspel die verloop as die pion geproduseer word in 'n direkte botsing tussen die projektiel en 'n gebonde valensnukleon in ${ }^{12} \mathrm{C}$. 
verkeer. Indien 'n nukleonprojektiel wat met 'n vrye nukleon bots ' $n$ groter kinetiese energie besit as die rusmassa van die meson, kan 'n meson in sodanige botsing vrygestel word. (Soos by alle kernreaksies word die werklike drumpelenergie bepaal deur die voorwaardes gestel deur energie en momentumbehoud.) Op soortgelyke wyse kan mesonproduksie ook bewerkstellig word deurdat die projektiel (nukleon) bots met 'n nukleon wat in 'n skyfkern gebind is, maar hier word gevind dat die reaksie by ' $n$ baie laer invalsenergie alreeds moontlik is, mits die voorwaarde van momentumbehoud bevredig word deur die beweging van die gebonde nukleon. Gevolglik kan 'n proses wat hierdie verloop volg, beskryf word as kwasievrye mesonproduksie.

Alhoewel sogenaamde subdrumpel-mesonproduksie reeds vir baie jare bestudeer is, is dit nog nie vantevore getoets of die proses volgens 'n kwasievrye meganisme geskied nie. Derhalwe is ' $n$ ondersoek ingestel om hierdie aspek te bestudeer.

'n Verdere motivering vir so 'n studie word gebaseer op die feit dat mesonproduksie gepaardgaan met 'n groot momentumoordrag. As in ag geneem word dat 'n groot momentum deur die onbepaaldheidsbeginsel gekoppel is aan 'n klein ruimtelike afstand, beteken dit gevolglik dat mesonproduksie ontstaan by ' $n$ botsing waar daar aansienlike oorvleueling van die twee botsende nukleone moet wees. Sodanige indringing mag dan veroorsaak dat dit nie noodwendig 'n goeie benadering is om die kwarkstruktuur van die nukleon te verwaarloos nie. Dus het die ondersoek dit ook implisiet ten doel gehad om vas te stel of die puntdeeltjiebenadering tot die nukleon geregverdig is vir mesonproduksie onder die nukleonnukleon-drumpel.

Die reaksie ${ }^{12} \mathrm{C}(\mathrm{p}, \mathrm{d} \pi)^{11} \mathrm{~B}$ is bestudeer ${ }^{15}$ by 'n invalsenergie van $220 \mathrm{MeV}$ ten einde die aard van die pionproduksiemeganisme te ondersoek. Soos vermoed is, word in figuur 8 gesien dat die gemete energieverdeling ooreenstem met ' $n$ teoretiese voorspelling wat berus op die veronderstelling dat die pion geproduseer word in 'n direkte botsing met ' $n$ valensnukleon van ${ }^{12} \mathrm{C}$. Derhalwe is die basiese reaksie beskryfbaar as ${ }^{1} \mathrm{H}(\mathrm{p}, \pi)^{2} \mathrm{H}$, en tree die res van die skyfkern suiwer as 'n toeskouer tot die proses op.

Nadat kwasievrye pionproduksie by ' $n$ invalsenergie onder die nukleon-nukleon-drumpelenergie as 'n belangrike meganisme aangewys is met die eksperiment ${ }^{15}$ by die NVS, is die aard van die reaksie bevestig ${ }^{22}$ deur navorsers elders. Gesien in die lig hiervan sou 'n kwantitatiewe bepaling van die breukdeel van die totale pionproduksiekansvlak nou waardevol wees.

\section{TOEKOMSTIGE TOEPASSING VAN DIE NAVORSINGSRESULTATE}

Alhoewel dit gewoonlik nie by fundamentele navorsing duidelik is waartoe die resultate sal lei in terme van toepassing nie, is dit tog nuttig om twee uiteenlopende aspekte te noem wat nou reeds aandag geniet, nl. vernietiging van reaktor-afval en protonterapie. Dit word in die vooruitsig gestel dat hierdie twee onderwerpe in die toekoms van toenemende belang gaan wees.

Die berging van radioaktiewe afval vanaf kernreaktors skep tans ' $n$ groot probleem. As gevolg hiervan, asook weens ander ongewenste newegevolge van kragopwekking met kernreaktors, toon die samelewing tans ' $n$ weerstand teen die bou van verdere kernkragsentrales. Ongelukkig lyk dit nie op hierdie stadium of alternatiewe metodes van kraglewering in die vraag kan voorsien nie, en is dit blykbaar ook nie realisties om aan te neem dat die mensdom in die toekoms sy gebruik van energie gaan afskaal nie. Gevolglik is dit onvermydelik dat die mens in die toekoms steeds meer van kernkrag afhanklik sal raak, in stryd met die begeerte van uitfasering daarvan.

'n Gepaste oplossing van die probleem, wat tans aandag geniet, is om die radioaktiewe vervalprodukte onskadelik te stel deur omsetting met kernreaksies. So 'n proses mag moontlik wees met 'n deeltjieversneller, en hiervoor word kennis benodig wat onder andere met voorewewigsreaksies ingewin kan word.

Dit is verblydend om te verneem dat eksperimentele gegewens ${ }^{+}$wat in hierdie oorsig beskryf is, opgeneem ${ }^{23224}$ is in 'n datastel ten einde 'n internasionale rekenprogram- en modelvergelykingsprojek ${ }^{25}$ van stapel stuur. Een van die belangrikste oogmerke van hierdie internasionale poging is juis daarop gemik om gebruikte kernbrandstof onskadelik te stel.

Kennis aangaande voorewewigsreaksies is ook nodig vir gebruik in protonterapie, was as mediese behandeling tans vinnig gevestig raak. Vir benutting in hierdie toepassing is dit veral die atoomkerne wat van biologiese belang is, soos suurstof en koolstof, wat 'n rol speel. Gevolglik is dit nodig om vertroud te wees met die aard en eienskappe van die reaksieprodukte wat in die pasient se liggaam geproduseer word tydens behandeling met energieke protonbundels.

Die vermelde toepassings is ongewoon, in die sin dat ons hier te doen het met gevalle waar die basiese dissipline waarop dit berus effens agter is by die behoefte.

Die resultate van enkele eksperimente by die NVS uitgevoer en in hierdie oorsig genoem, dui daarop dat 'n aktuele en realistiese basiese kernfisikanavorsingsprogram in SuidAfrika met sukses onderneem word.

\section{SUMMARY}

Since the commissioning of the separated sector cyclotron of the National Accelerator Centre in 1986, South Africa has been in a position to conduct basic nuclear physics research at intermediate energies. Selected examples of completed projects are reviewed.

The energy transferred by nucleons to nuclear matter was investigated for a representative set of atomic nuclei at incident energies in the range of 80 to $200 \mathrm{MeV}$. It was found that a statistical multistep direct theory accounts for the experimental continuum spectra. Therefore the reaction mechanism proceeds as a series of nucleon-nucleon collisions inside the target nucleus, with a certain probability of one of the participants in the interaction escaping from the nuclear volume. In such a case the ejectile removes so much energy from the system that the remaining energy is rapidly equilibrated in the recoiling nucleus. Further emissions can then result from particles evaporating from this nucleus according to the known compound-nuclear mechanism.

It was also concluded from these studies that the strength of the effective nucleon-nucleon interaction displays an incident-energy dependence that is consistent with the known behaviour of the optical potential. Multiparticle 
pre-equilibrium emission, with two energetic nucleons emerging from the reaction, becomes more prevalent at higher incident energy, as would be expected. The experiments provide quantitative information on this matter.

The direct knockout of protons to discrete states of the final recoiling nucleus was also studied. It was confirmed that the reaction mechanism by means of which the process proceeds is relatively simple at intermediate energies. Consequently experimental studies of knockout reactions are able to yield reliable information on the momentum distribution of nucleons in shell-model orbitals, as well as details of the occupation probabilities.

The relationship between knockout and pre-equilibrium processes was explored further by means of measurements of coincident protons that are emitted during the interaction of protons with various target nuclei. Evidently the reaction mechanism is initiated by an interaction that would normally lead to knockout of the struck nucleon. However, a large proportion of these nucleons suffer further violent rescatterings. Consequently they behave as intranuclear projectiles that transfer their kinetic energy in a preequilibrium process. Even when the rescattering effect is severe, the characteristics of the initial quasifree knockout collision are retained.

The tendency of nucleons to form temporary groupings, or clusters in nuclei, is a well established phenomenon. However, quantitative information has proved to be somewhat elusive. For example, whereas the knockout of alpha-clusters with protons yields spectroscopic factors that are in agreement with theoretical estimates, similar determinations with alpha-particle probes indicate clustering probabilities that are enhanced by many orders of magnitude. It was demonstrated that the results obtained with the two probes, which are projectiles with dissimilar characteristics, are in agreement if the alpha-particle energy is increased to a value at which it penetrates the target nucleus to the same extent as protons. Thus it is found that both projectiles, viz protons and alpha-particles, give the same alpha-clustering probability if care is taken to ensure that the same region of the target nucleus is sampled.

Pions, which are the field particles of the strong nuclear force, can be produced as free entities in reactions of protons with nuclei at incident energies which are lower than the value at which a pion is released in a free nucleonnucleon collision. This so-called subthreshold pion production could originate from various types of mechanisms. Obviously the lack of understanding regarding such a fundamental process is highly undesirable. Because the momentum transfer involved in pion production is rather high, a large degree of spatial overlap between the nucleons participating in the interaction is inevitable. Consequently the production process may be dependent on the quark structure of the nucleon, which is generally assumed to be unimportant to most phenomena that are studied in nuclear physics. Although the scope of the present measurements was too limited to explore this issue to the desired extent, it was nevertheless possible to demonstrate that the production of pions is driven to a large degree by a quasifree interaction between the projectile and a bound target nucleon. This knowledge paves the way for an eventual determination of the influence of the substructure of the nucleon in the nuclear environment.
It is usually not possible to predict future applications that will result from fundamental research that is performed at present. However, it is already clear that the results that have been obtained thus far in the programmes described in this review will probably be invaluable to applications in medicine, and also to the problems associated with the incineration of nuclear waste from reactors.

Proton therapy has already shown its potential as a medical procedure, and consequently there is a need for an accurate understanding of the aspects of nuclear physics as they pertain to biologically important target material. Knowledge regarding the reaction mechanisms, which was gained in the present basic research programme, would serve to facilitate the planning that is required for the routine treatment of patients.

The generation of power with nuclear reactors suffers from the undesirable production of radioactive waste that creates serious disposal problems. Unfortunately mankind will have to live with this issue, as alternative sources of energy are unlikely to satisfy the demand in the foreseeable future. For that reason the incineration of radioactive waste by means of nuclear reactions is an option that require careful consideration. Therefore the experimental information that was obtained in the basic research programme would also be useful in the development of the technology to deal with the incineration of radioactive waste.

These examples of results from work with the South African accelerator facility illustrate that a viable and promising research programme in fundamental nuclear physics has been pursued.

\section{ERKENNING}

Prof. H.B. Geyer en dr. S.J. Mills word bedank vir waardevolle kommentaar op die inhoud van die manuskrip.

\section{LITERATUURVERWYSINGS}

1. Förtsch, S.V., Cowley, A.A., Pilcher, J.V., Whittal, D.M., Lawrie, J.J. van Staden, J.C. \& Friedland, E. (1988). Continuum yields form ${ }^{12} \mathrm{C}(\mathrm{p}, \mathrm{p}$ ') at incident proton energies of 90 and 200 MeV, Nucl. Phys., A483, 258-270.

2. Cowley, A.A., Förtsch, S.V., Lawrie, J.J., Whittal, D.M., Smit, F. D. \& Pilcher, J.V. (1990). Continuum protons from the inclusive reaction ${ }^{197} \mathrm{Au}\left(\mathrm{p}, \mathrm{p}^{\prime}\right)$ at incident energies between 100 and $200 \mathrm{MeV}$, Z.Phys., A336, 189-195.

3. Lawrie, J.J., Whittal, D.M. \& Cowley, A.A. (1990). Continuum analyzing power for ${ }^{4} \mathrm{He}(\mathrm{p}, \mathrm{p})$ ) at $100 \mathrm{MeV}, P h y s$. Rev. C, 42, 778-780.

4. Cowley, A.A., Van Kent, A., Lawrie, J.J., Förtsch, S.V., Whittal, D.M., Pilcher, J.V., Smit, F.D., Richter, W.A., Lindsay, R., Van Heerden, I.J., Bonetti, R. \& Hodgson, P.E. (1991). Preequilibrium proton emission induced by 80 and $120 \mathrm{MeV}$ protons incident on ${ }^{90} \mathrm{Zr}$, Phys. Rev. C, 43 678-686.

5. Förtsch, S.V., Cowley, A.A., Lawrie, J.J., Whittal, D.M., Pilcher, J.V. \& Smit, F D. (1991) Continuum protons from ${ }^{58} \mathrm{Ni}\left(\mathrm{p}, \mathrm{p}^{\prime}\right)$ at incident energies between 100 and $200 \mathrm{MeV}$, Phys. Rev.C,43, $691-700$.

6. Richter, W.A., Cowley, A.A., Lindsay, R., Lawrie, J.J., Förtsch, S.V., Pilcher, J.V., Bonetti, R. \& Hodgson P.E. (1992). Statistical multistep direct calculations for (p,p') continuum spectra up to $200 \mathrm{MeV}$, Phys. Rev. C, 46, 1030-1044.

7. Richter, W.A. Cowley, A.A. Hillhouse. G.C., Stander, J. A., Koen, J. W., Steyn, S. W., Lindsay, R., Julies, R.E., Lawrie, J.J., Pilcher, J.V.\& Hodgson P.E. (1994). Preequilibrium (p,p') measurements and calculations for ${ }^{90} \mathrm{Zr}$ and neighboring nuclei for incident energies up to $200 \mathrm{MeV}$, Phys. Rev. C, 49, 10011011 . 
8. Cowley, A.A., Pilcher, J.V., Lawrie, J.J.\& Whiıtal, D.M. (1989). Protons of $200 \mathrm{MeV}$ incident on ${ }^{12} \mathrm{C} .11$. Quasifree proton knockout, Phys. Rev. C, 40, 1950-1958.

9. Cowley, A.A., Lawrie, J.J., Hillhouse, G.C., Whittal, D.M. Förtsch, S.V., Pilcher, J.V., Smit, F.D.\& Roos P.G. (1991). Quasifree knockout in ${ }^{16} \mathrm{O}(\mathrm{p}, 2 \mathrm{p}) 15 \mathrm{~N}$ at an incident energy of $151 \mathrm{MeV} .$, Phys. Rev, C, 44, 329-335.

10. Cowley, A.A., Pilcher, J.V., Lawrie, J.J. \& Whittal, D.M. (1988). Coincident proton emisssion from the continuum induced by $200 \mathrm{MeV}$ protons on ${ }^{12} \mathrm{C}, \mathrm{Phys}$, Lett. B, 201, 196-200.

1 1. Pilcher, J.V., Cowley, A.A., Whittal, D.M. \& Lawrie J.J. (1989). Protons of $200 \mathrm{MeV}$ incident on ${ }^{12} \mathrm{C}$.I. Coincident proton emission from the continuum. Phys. Rev. C, 40, 1937-1949.

12. Cowley, A.A., Fortch, S.V., Lawrie, J.J., Pilcher, J.V., Smit, F.D. \& Whittal, D.M. (1990). Importance of nucleon-nucleon scattering in the interaction of protons with ${ }^{197} \mathrm{Au}$ at $200 \mathrm{MeV}$, Europhys. Lett., 13,37-41.

13. Förtsch, S.V., Cowley, A. A., Lawrie, J.J., Pilcher, J.V., Smit, F.D. \& Whittal D.M. (1993). Coincident proton emission induced by $200 \mathrm{MeV}$ protons on ${ }^{197} \mathrm{Au}$, Phys.Rev.C, 48, 743755 .

14. Whittal, D.M., Cowley, A.A., Pilcher, J.V., Fortsch, S.V., Smit, F.D. \& Lawrie, J.J. (1990). Quasifree knockout of charged particles from ${ }^{4} \mathrm{He}$ with $100 \mathrm{MeV}$ protons, Phys. Rev. C, 42, 309-330.

15. Cowley, A.A., Roos, P.G., Lawrie, J.J., Smit, F.D., Pilcher,J.V., Fortsch, S.V., Steyn, G.F. \& Hillhouse, G.C. (1992). Quasifree subthreshold pion production in the reaction ${ }^{12} \mathrm{C}\left(\mathrm{p}, \mathrm{d} \pi^{+}\right)^{1 /} \mathrm{B}$, Phys. Rev. C, 45, 1745-1747.

16. Feschbach, H., Kerman, A. \& Koonin, S. (1980). The statistical theory of multistep compound and direct reactions, Ann. Phys. (N.Y.), 124, 429-476.

17. Scobel, W., Trabandt, M., Blann, M., Pohl, B.A., Remington, B.R., Byrd, R.C. Foster, C.C., Bonetti, R., Chiesa, C. \& Grimes, S.M. (1990). Preequilibrium $(p, n)$ reaction as a probe for the effective nucleon-nucleon interaction in multistep direct processes, Phys. Rev. C, 41, 2010-2020.

18. Gadioli, E. \& Hodgson, P.E. Pre-Equilibrium Nuclear Reactions (Oxford University Press, Oxford, 1992) p. 1-513.

19. Roos, P.G., Chant, N.S., Cowley, A.A., Goldberg, D.A., Holmgren, H.D. \& Woody, R (1977). Absolute spectroscopic factors from the $(\mathrm{p}, \mathrm{p} \alpha)$ reaction at $100 \mathrm{MeV}$ on $1 \mathrm{p}$-shell nuclei, Phys. Rev.C, 15, 69-83.

20. Wang, C.W., Chant, N.S., Roos, P.G., Nadasen, A. \& Carey, T.A. (1980). Quasi-free $(\alpha, 2 \alpha)$ reaction induced by $140 \mathrm{MeV}$ alpha particles on ${ }^{9} \mathrm{Be},{ }^{12} \mathrm{C},{ }^{16} \mathrm{O}$ and ${ }^{20} \mathrm{Ne}$, Phys.Rev.C, $21,1705-$ 1717.

21. Sien bv. Frauenfelder. H. \& Henley, E.M. (1974) Subatomic Physics (Prentice-Hall, Englewood Cliffs, New Jersey).

22. Rohdjess, H., Scobel, W., Meyer, H.O., Pancella, P.V., Pate, S.F., Pickar, M.A., Pollock, R.E., v. Przewoski, B., Rinckel, T., Singh, P.P., Sperison. F \& Sprute, L. (1993). Total cross section for $\mathrm{p}+\mathrm{d} \bullet \mathrm{p}+\mathrm{d}+\pi^{\circ}$ close to threshold, Phys Rev. Lett., 70, 28642867.

23. Nagel, P. (1993) persoonlike mededeling.

24. Blann, M. (1993) persoonlike mededeling.

25. Blann, M. \& Nagel, P. (1992). Draft Specifications for an International Code and Model Intercomparison for Intermediate Energy Reactions NEA/NSC/DOC (92) 1, p. 1-6. 